\title{
FURTHER SIGNS OF AN ENRICHED MANTLE SOURCE UNDER THE NEOPROTEROZOIC ARAÇUAÍ-RIBEIRA MOBILE BELT
}

\author{
ISABEL PEREIRA LUDKA ${ }^{1}$ AND CRISTINA MARIA WIEDEMANN-LEONARDOS ${ }^{1,2}$
}

\begin{abstract}
Isolated small bodies of Neoproterozoic coronitic gabbros crop out in the states of Espírito Santo (Jacutinga and Itaoca) and Rio de Janeiro (Amparo), in the central portion of the Araçuaí-Ribeira Mobile Belt. The rocks from Jacutinga and Itaoca are mainly gabbronorites and show a wide range of modal/textural varieties recording crystal-setting processes normally found in layered intrusions. The Amparo intrusion is formed by a coronitic rock, also present as layers in Jacutinga and Itaoca. The primary mineral assemblage consists of olivine, opx, cpx, plagioclase, ilmenite, Ti-magnetite and sulphides. Coronitic overgrowths related to the olivine-plagioclase reaction form concentric rims of opx, amphibole and simplectitic amphibole-spinel around olivine cores. They are all very similar in shape and composition pointing towards similar physical-chemical crystallization conditions. Different geothermometric measurements yielded crystallization temperatures around $800^{\circ} \mathrm{C}$, which are close to those calculated for primary opx-cpx pairs $\left(800 / 940^{\circ} \mathrm{C}\right)$. The absence of regional deformational and metamorphic paragenesis is compatible with their intrusion into the middle/ lower crust during a late collisional phase. A long lasting cooling environment at a late magmatic stage induced the sub-solidus reactions.

Low K sub-alkaline signatures with clear enrichment in some incompatible elements such as Ba, Sr and LREE associated with high ${ }^{87} \mathrm{Sr} /{ }^{86} \mathrm{Sr}$ initial ratios (around 0.706-0.708) are anomalous chemical characteristics of these gabbros. Enriched mantle types (EM1, EM2 and HIMU) with high Sr-initial ratios are frequently found in the Southern Hemisphere. The chemical anomalies obtained in this study could be related to largescale phenomena, similar to the Dupal anomaly.
\end{abstract}

Keywords: mantle geochemistry, gabbro-norites, olivine coronas.

INTRODUCTION The Jacutinga and Itaoca gabbros are located in the southern region of Espírito Santo State and the Amparo outcrop lies in the Nova Friburgo mountainous region of Rio de Janeiro (Fig.1). Despite the absence of geochronology data, field evidence shows they are part of the late- to post-collisional magmatism of the Araçuaí-Ribeira Mobile Belt, formed at the end of the Pan-AfricanBrasiliano orogeny. The preservation of primary igneous structures and only weak signs of deformation, restricted to few lineaments, show that the compressional effects of the Brasiliano event are trivial. The country rocks of the gabbro intrusions are 580-590 Ma old ortho and paragneisses (Söllner et al. 1991).

Field, petrographic and preliminary geochemical data of the Jacutinga gabbroic intrusion were previously discussed by Fontes $\mathrm{et} \mathrm{al}$. (1981), Wiedemann and Lammerer (1983), Wiedemann and Ludka (1984), Wiedemann et al. (1986a), Wiedemann et al. (1986b), Ludka (1991) and Wiedemann et al. (1995). Preliminary chemical analyses of the Itaoca gabbros (Ladwig 1988, Offman 1990) were compared to other mafic occurrences of this region. Braun and Cavalcante (1980) first mapped Amparo.

Comparing geochemical data from several examples within the literature, Ludka et al. (1998) showed the unique regional geochemical

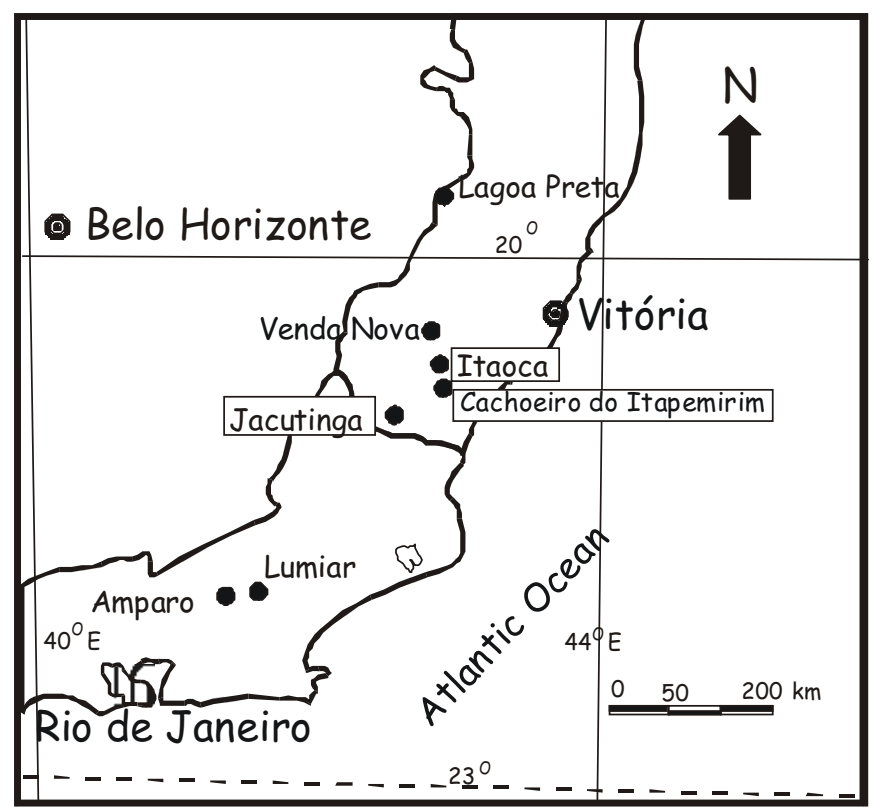

Figure 1 - Location map of the studied gabbroic occurrences in the states of Rio de Janeiro and Espírito Santo. signature of the underlying mantle. In this study complementary field, petrographic, geochemical and isotopic data characterized these basic rocks as well preserved mantelic differentiates.

GEOLOGY AND PETROGRAPHY The rocks from Jacutinga and Itaoca are mainly gabbro-norites. They grade from leucogabbronorite to pyroxenite, covering a wide range of modal/textural/grainsize varieties. The contrasting aspects (color index and grain size) in these rocks show several processes of crystal setting normally found in layered intrusions such as: igneous lamination, poikilitic textures, cumulates, adcumulates and heteroadcumulates crystals (Cox et al.1979) and interlayering of contrasting minerals (rhythmic layering). Olivine, opx, cpx, plagioclase, ilmenite, Ti-magnetite and sulphides form the common primary mineral assemblage. In few areas, along lineaments or within the intrusion margins, amphibole and ilmenite/Timagnetite exsolutions replace both the pyroxenes. In the Jacutinga intrusion, biotite (meroxen/lepidomelan) and garnet was locally observed.

Poikilitic (oikocrysts of opx, cpx, plagioclase and amphibole) and coronitic texture are abundant in all 3 bodies. Coronites occur as interlayers in the Jacutinga and Itaoca gabbros. The Amparo intrusion consists exclusively of this coronitic rock, also known as hyperite. Its mineral proportion varies from place to place. This rock is characterized by a coronitic overgrowth that resulted from the olivineplagioclase reaction, forming concentric layers of bronzite II, pargasitic amphibole and spinel symplectite around olivine. The modal analysis shows that Jacutinga and Amparo coronites are very similar, the Itaoca is more mafic. Very similar coronas are also found in the Lagoa Preta gabbroic massif (Vieira et al. 1993), and in the hyperites gabbros from the Bamble area, in the Caledonides of Norway (Dam 1995).

Microprobe analysis from the three intrusions records homogeneous mineral compositions. Primary crystals show no significant chemical zoning. This is a clear indication of crystal-liquid equilibrium and, in the case of the corona formation, well-developed sub-solidus reactions. Low forsterite contents (> Fo70) of olivine together with very high anorthite contents (> An94) in plagioclase suggest high degree of $\mathrm{Mg}$ diffusion during the corona reaction or the modification of a primary, mantle-derived melt by a complex differentiation process.

Comparative geologic, petrographic and mineralogical data are presented on Table 1 .

GEOTHERMOMETRY The crystallization temperature of the primary orthopyroxene-clinopyroxene pair was calculated using three different methods (Wood and Banno 1973, Weels 1977, and the software QUILF from Andersen, 1992). The results are coherent for each sample, under the range of the uncertainties expected for these methods (Table 2). The coronitic rocks from Amparo give the highest temperature for the pyroxenes pairs.

1 - Departamento de Geologia, UFRJ, Rio de Janeiro, Brazil. E-mail: ludka@igeo.ufrj.br

2 - Instituto de Geociências, UNB, C.P. 04350, 70919-970 Brasília, Brazil. E-mail: wiedeman@unb.br 
Table 1 - Main geological and petrographic features of Amparo, Jacutinga and Itaoca

\begin{tabular}{|c|c|c|c|}
\hline Characteristics & Amparo & Jacutinga & Itaoca \\
\hline shape & ellipsoidal & Elongated ellipsoid & ellipsoidal \\
\hline cropping out area & $4 \mathrm{Km}^{2}$ & $14 \mathrm{Km}^{2}$ & $11 \mathrm{Km}^{2}$ \\
\hline field occurrence & $\mathrm{cm} /$ metric boulders & $\mathrm{cm} /$ decametric boulders & $\mathrm{cm} /$ decametric boulders \\
\hline rock classification & olivine leucogabbro-norite & olivine leuco/melagabbronorite & $\begin{array}{c}\text { olivine leuco/ } \\
\text { melagabbro- } \\
\text { norite/pyroxenite }\end{array}$ \\
\hline mineral orientation & not observed & igneous lamination & igneous lamination \\
\hline evidence of igneous layering & not observed & $\begin{array}{c}\text { sharp contact between } \\
\text { contrasting compositional layers }\end{array}$ & $\begin{array}{l}\text { centimetric rithmic } \\
\text { layering }\end{array}$ \\
\hline poikilitic texture & Cpx and opx oikocrysts & Amphibole oikocrysts & $\begin{array}{l}\text { opx oikocrysts, } \\
\text { plagioclase and } \\
\text { amphibole }\end{array}$ \\
\hline primary paragenesis & ol-opx-cpx-plg-op & $\begin{array}{c}\text { ol-opx-cpx-plg-op- } \\
\text { biot?(meroxeno/lepido-melano) }\end{array}$ & ol-opx-cpx-plg-op \\
\hline cumulate minerals & ol-cpx-opx-plg & ol-cpx-plg & ol-cpx-opx \\
\hline primary minerals & $\begin{array}{l}\begin{array}{c}\text { chrysolite/hyalosiderite } \\
\left(\mathrm{Fo}_{67-73}\right)\end{array} \\
\text { enstatite }\left(\mathrm{Wo}_{0.6-3.4} \mathrm{En}_{69.8-}\right. \\
\left.75 . \mathrm{Fs}_{23-29}\right) \\
\text { diopside }\left(\mathrm{Wo}_{46-47} \mathrm{En}_{42-44}-\right. \\
\left.\mathrm{Fs}_{9-10}\right) \\
\text { plagioclase }\left(\mathrm{An}_{87-98}\right) \\
\end{array}$ & $\begin{array}{c}\text { hyalosiderita }\left(\mathrm{Fo}_{68}\right) \\
\text { enstatite }\left(\mathrm{Wo}_{0.8-4.2-} \mathrm{En}_{40-52}-\mathrm{Fs}_{6-58}\right) \\
\text { diopside }\left(\mathrm{Wo}_{44-77} \mathrm{En}_{33-44}-\mathrm{Fs}_{8-21}\right) \\
\text { plagioclase }\left(\mathrm{An}_{38-93}\right) \\
\text { biot?(meroxen-lepidomelane) }\end{array}$ & $\begin{array}{c}\text { Chrysolite }\left(\mathrm{Fo}_{78}\right) \\
\text { enstatite }\left(\mathrm{Wo}_{0.5-4 .-} \mathrm{En}_{62-79^{-}}\right. \\
\left.\mathrm{Fs}_{19-35}\right) \\
\text { diopside }\left(\mathrm{Wo}_{46-48} \mathrm{En}_{40-45^{-}}\right. \\
\left.\mathrm{Fs}_{6-12}\right) \\
\text { plagioclase }\left(\mathrm{An}_{82-92}\right)\end{array}$ \\
\hline signs of mineral deformation & not observed & $\begin{array}{l}\text { elongated and breached coronas } \\
\text { and pyroxenes along the Iurú- } \\
\text { Mimoso do Sul lineament }\end{array}$ & $\begin{array}{c}\text { slightly deformed } \\
\text { minerals along restrict } \\
\text { lineaments }\end{array}$ \\
\hline sub-solidus paragenesis & $\begin{array}{c}\text { amphibole, opx, spinel, } \\
\text { ore minerals } \\
\end{array}$ & $\begin{array}{c}\text { amphibole, opx, spinel, ore } \\
\text { minerals }\end{array}$ & $\begin{array}{c}\text { amphibole, opx, spinel, } \\
\text { ore minerals }\end{array}$ \\
\hline $\begin{array}{l}\text { composition of secondary } \\
\text { corona minerals }\end{array}$ & $\begin{array}{c}\text { enstatite }\left(\mathrm{Wo}_{0.2-0.8}-\mathrm{En}_{69-76}\right. \\
\left.\mathrm{Fs}_{23-30 .}\right) \\
\text { XMg amphibole:69-81 } \\
\text { XMg spinel:45-59 }\end{array}$ & $\begin{array}{c}\text { enstatite }\left(\mathrm{Wo}_{0.5}-\mathrm{En}_{76}-\mathrm{Fs}_{23}\right) \\
\text { XMg amphibole:73-76 } \\
\text { XMg spinel:47 }\end{array}$ & $\begin{array}{l}\text { enstatite }\left(\mathrm{Wo}_{0.5-0.6}-\mathrm{En}_{77-79}\right. \\
\left.\mathrm{Fs}_{21-23}\right) \\
\text { XMg amphibole: } 87-90 \\
\text { XMg spinel:56 }\end{array}$ \\
\hline
\end{tabular}

The equilibrium temperature for the corona minerals was calculated using the software QUILF for the olivine-orthopyroxene-spinel system and the method proposed by Perchuck et al. (1985). This method is based on the $\mathrm{Fe} / \mathrm{Mg}$ ratio (\#Mg) between the coexistent orthopyroxene and amphibole in the corona. The observed differences for each sample are in the error range. Due to the higher $\mathrm{Mg}$-content of olivine, Amparo rocks show again the highest temperatures (Table 3 ). These temperatures are very close to those found by Bas Dam (1995) for the coronitic gabbros from the Bamble area, in Norway.

GEOCHEMISTRY Major, minor and trace element geochemistry, including rare-earth elements (REE) and Sr-isotopes analyses were performed at the laboratories of the Institut für Allgemeine und Angewandte Geologie of the Maximillian University (IAAG/LMU), in Munich, Germany, and at GEOSOL/Brazil. XRF, ICP-AES and mass spectrometries were the techniques used.

From the total of 29 analysis, 11 were selected and are on Table 4 Using traditional rock classification diagrams a low-K sub-alkaline signature was obtained even when different indicators were chosen, such as: $\mathrm{Na}_{2} 0+\mathrm{K}_{2} \mathrm{O} X \mathrm{SiO}_{2}$ diagram from Cox et al. (1979) and Irvine and Baragar (1971), $\mathrm{K}_{2} \mathrm{O}$ X SiO from Middlemost (1975), $\mathrm{P}_{2} \mathrm{O}_{5}$ X Zr diagram from Winchester and Floyd (1976), $\mathrm{Cr}$ X Ti from Pearce (1975), $\mathrm{SiO} \times \mathrm{Zr} / \mathrm{TiO}$ from Winchester and Floyd, (1977). The chemical classification proposed by Middlemost (1985) and Le Maitre (1989) classifies these rocks as basalt, tholeiitic basalt, picrobasalt and picrite.

The spidergrams of figure 2 show similar chemical signatures. Ba, $\mathrm{Sr}$ and LREE enrichments and $\mathrm{Rb}, \mathrm{K}$ and HREE depletions are comparable for all three rock-types in the three intrusions.

The REE-patterns of all investigated samples show strong LREE enrichments (Fig. 3) and absence of Eu anomalies, despite the high plagioclase content in some rocks. The high positive $\mathrm{La}_{\mathrm{cn}} / \mathrm{Lu}_{\mathrm{cn}}$ ratio varies from 9 to 21 for Amparo, from 2.8 to 15 for Jacutinga and 3.6 to 8.5 for Itaoca. When normalized to OIB values, the REE pattern from all intrusions is horizontal and with comparative lower total REE values. The OIB normalized spidergrams show depletion for some
Table 2 - Calculated temperatures of orthopyroxene-clinopyroxene pairs from Amparo, Jacutinga and Itaoca gabbros

\begin{tabular}{|c|c|c|c|}
\hline & $\begin{array}{l}\text { Wood \& } \\
\text { Banno }\end{array}$ & Wells & Quilf \\
\hline \multicolumn{4}{|c|}{ Amparo } \\
\hline A6.2 & $970^{\circ} \pm 60^{\circ} \mathrm{C}$ & $940^{\circ} \pm 70^{\circ} \mathrm{C}$ & $951^{\circ} \pm 64^{\circ} \mathrm{C}$ \\
\hline A8.1 & $947^{\circ} \pm 60^{\circ} \mathrm{C}$ & $958^{\circ} \pm 70^{\circ} \mathrm{C}$ & $948^{\circ} \pm 94^{\circ} \mathrm{C}$ \\
\hline \multicolumn{4}{|c|}{ Jacutinga } \\
\hline $\mathrm{J} 475$ & $801^{\circ} \pm 6^{\circ}{ }^{\circ} \mathrm{C}$ & $832^{\circ} \pm 7 \mathrm{o}^{\circ} \mathrm{C}$ & $700^{\circ} \pm 40^{\circ} \mathrm{C}$ \\
\hline J343 & $782^{\circ} \pm 60^{\circ} \mathrm{C}$ & $814^{\circ} \pm 7 \mathrm{o}^{\circ} \mathrm{C}$ & $756^{\circ} \pm 40^{\circ} \mathrm{C}$ \\
\hline \multicolumn{4}{|l|}{ Itaoca } \\
\hline ita76 & $817^{\circ} \pm 60^{\circ} \mathrm{C}$ & $855^{\circ} \pm 7 \mathrm{o}^{\circ} \mathrm{C}$ & $858^{\circ} \pm 78^{\circ} \mathrm{C}$ \\
\hline
\end{tabular}

Table 3 - Calculated equilibrium temperatures of corona minerals from Amparo, Jacutinga and Itaoca coronites

\begin{tabular}{|c|c|c|c|c|c|}
\hline Sample & minerals & ITA76 & $\mathrm{J} 348$ & A-2 & A-8.1 \\
\hline QUILF & Ol-Opx-Sp & $\begin{array}{r}707^{\circ} \mathrm{C} \\
\pm 50^{\circ} \mathrm{C} \\
\end{array}$ & $\begin{array}{r}845^{\circ} \mathrm{C} \\
\pm 45^{\circ} \mathrm{C} \\
\end{array}$ & $\begin{array}{c}880^{\circ} \mathrm{C} \\
\pm 64^{\circ} \mathrm{C} \\
\end{array}$ & $\begin{array}{r}847^{\circ} \mathrm{C} \\
\pm 72^{\circ} \mathrm{C} \\
\end{array}$ \\
\hline PERCHUCK & Opx-Amph & $\begin{array}{r}700^{\circ} \mathrm{C} \\
\pm 50^{\circ} \mathrm{C}\end{array}$ & $\begin{array}{r}800^{\circ} \mathrm{C} \\
\pm 50^{\circ} \mathrm{C}\end{array}$ & $\begin{array}{r}900^{\circ} \mathrm{C} \\
\pm 50^{\circ} \mathrm{C}\end{array}$ & $\begin{array}{l}900^{\circ} \mathrm{C} \\
\pm 50^{\circ} \mathrm{C}\end{array}$ \\
\hline
\end{tabular}

incompatible elements, especially $\mathrm{Rb}$ and $\mathrm{K}$. Compared to continental crust values; these rocks show LREE-enrichments, and HREE depletion. The HREE depletion suggests a generation process through relative small degrees of mantle partial melting, as proposed by Bellieni et al. (1984) for the Mesozoic basalts from the Paraná basin.

Another characteristic of these rocks is the high ${ }^{87} \mathrm{Sr} /{ }^{86} \mathrm{Sr}$ initial ratios found for Jacutinga and Itaoca (Table 5). For Amparo no 

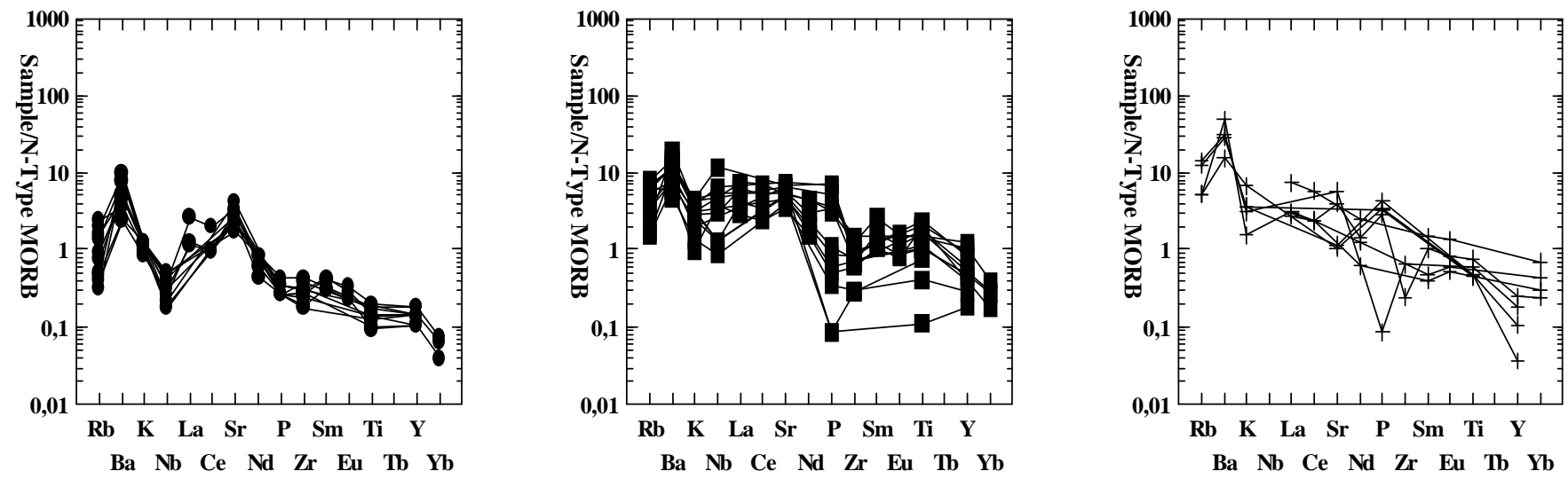

Figure 2 - N-type MORB (Sun \& McDonough 1989) normalized spidergram for gabbroic rocks.- Legend: circle: Amparo; square: Jacutinga; (+): Itaoca;
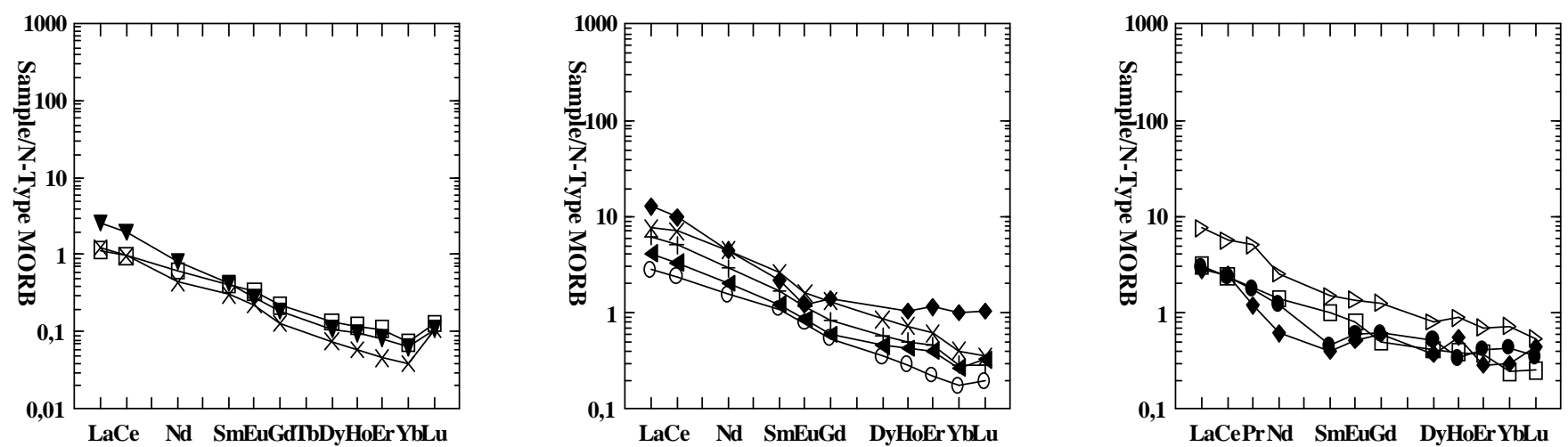

Figure 3 - N-type MORB (Sun \& McDonough 1989) normalized REE-patterns of gabbroic rocks. Legend: left-Amparo: triangle-A81; square-A2; (X) A6.2. center-Jacutinga: triangle-J470; losangle:J472; circle: J475; cross: J471; (X): J472; rigth-Itaoca: triangle-Ita25; square-Ita31; losangle Ita34; circle:Ita95.

Table 4 - Selected chemical analysis of Amparo (Axx, coronite), Jacutinga (Jxxx, gabbro-norite) and Itaoca (Ita31 coronite, ita34 and 95 pyroxenite, Ita 25 gabbro-norite) rocks

\begin{tabular}{|c|c|c|c|c|c|c|c|c|c|c|c|}
\hline sample & $\mathrm{A} 2$ & A6.2 & A8.1 & $\mathrm{J} 470$ & J471 & J472 & J475 & Ita25 & Ita31 & Ita34 & Ita95 \\
\hline $\mathrm{SiO}_{2}$ & 41.46 & 42.06 & 43.40 & 46.46 & 45.72 & 44.70 & 41.90 & 46.82 & 45.88 & 48.39 & 48.54 \\
\hline $\mathrm{Al}_{2} \mathrm{O}_{3}$ & 15.98 & 19.09 & 18.01 & 17.57 & 18.34 & 18.20 & 15.00 & 22.63 & 21.02 & 6.47 & 8.78 \\
\hline $\mathrm{FeO}$ & 10.29 & 8.54 & 8.09 & 8.32 & 8.89 & 9.56 & 10.70 & 5.15 & 7.66 & 6.27 & 6.93 \\
\hline $\mathrm{MnO}$ & 0.15 & 0.13 & 0.14 & 0.18 & 0.18 & 0.21 & 0.24 & 0.15 & 0.12 & 0.34 & 0.14 \\
\hline $\mathrm{MgO}$ & 20.73 & 16.07 & 14.73 & 8.60 & 7.24 & 6.87 & 7.40 & 5.64 & 6.94 & 15.93 & 13.52 \\
\hline $\mathrm{K}_{2} \mathrm{O}$ & 0.08 & 0.06 & 0.09 & 0.23 & 0.21 & 0.31 & 0.07 & 0.22 & 0.11 & 0.26 & 0.49 \\
\hline $\mathrm{P}_{2} \mathrm{O}_{5}$ & 0.04 & 0.03 & 0.04 & 0.10 & 0.39 & 0.36 & 0.06 & 0.01 & 0.33 & 0.38 & 0.40 \\
\hline LOI & 1.26 & 1.25 & 1.10 & 1.40 & 1.28 & 1.57 & 1.36 & 0.68 & 1.5 & 1.7 & 1.7 \\
\hline Summe & 101.72 & 100.48 & 100.05 & 100.15 & 100.57 & 100.49 & 100.03 & 99.53 & 99.78 & 98.66 & 100.25 \\
\hline $\mathrm{Ba}$ & 29 & 49 & 16 & 74 & 58 & 69 & 37 & 200 & 313 & & 97 \\
\hline $\mathrm{Rb}$ & 0.9 & 0.22 & 0.28 & 3.87 & 2.1 & 0.92 & 7 & 8 & 3 & & 3 \\
\hline $\mathrm{La}$ & 2.91 & 3.17 & 6.62 & 10.53 & 15.49 & 18.80 & 7.11 & 18.70 & 7.84 & 6.99 & 7.50 \\
\hline $\mathrm{Ce}$ & 7.40 & 7.31 & 14.51 & 24.97 & 37.85 & 52.95 & 18.05 & 42.85 & 18.01 & 18.25 & 17.72 \\
\hline $\mathrm{Nd}$ & 4.54 & 3.20 & 6.01 & 14.76 & 21.47 & 32.86 & 11.32 & 18.59 & 10.32 & 4.55 & 8.99 \\
\hline $\mathrm{Sm}$ & 1.10 & 0.80 & 1.12 & 3.24 & 4.43 & 6.97 & 2.81 & 3.91 & 2.66 & 1.05 & 1.21 \\
\hline $\mathrm{Eu}$ & 0.34 & 0.24 & 0.29 & 0.87 & 1.18 & 1.65 & 0.80 & 1.38 & 0.83 & 0.54 & 0.60 \\
\hline $\mathrm{Gd}$ & 0.81 & 0.48 & 0.69 & 2.21 & 3.03 & 4.81 & 1.97 & 4.75 & 1.88 & 2.19 & 2.26 \\
\hline Dy & 0.61 & 0.34 & 0.50 & 2.08 & 2.59 & 3.86 & 1.61 & 3.71 & 1.87 & 1.73 & 2.36 \\
\hline Ho & 0.12 & 0.06 & 0.10 & 0.43 & 0.51 & 0.74 & 0.29 & 0.90 & 0.39 & 0.56 & 0.34 \\
\hline $\mathrm{Er}$ & 0.33 & 0.14 & 0.25 & 1.19 & 1.36 & 1.85 & 0.66 & 2.07 & 1.12 & 0.87 & 1.25 \\
\hline $\mathrm{Yb}$ & 0.22 & 0.12 & 0.20 & 0.82 & 0.87 & 1.21 & 0.53 & 2.19 & 0.74 & 0.91 & 1.33 \\
\hline $\mathrm{Lu}$ & 0.058 & 0.05 & 0.05 & 0.15 & 0.13 & 0.16 & 0.09 & 0.25 & 0.11 & 0.20 & 0.16 \\
\hline
\end{tabular}

isotopic data was available. According to the preliminary results two distinct groups of high ${ }^{87} \mathrm{Sr} /{ }^{86} \mathrm{Sr}$-initial ratios could be distinguished: around 0.708 and 0.705 . The results confirm the separation into two main groups corresponding to those characterized for the Paraná basin basalts, 0.705-0.706 and 0.708-0-711(Cordani et al. 1988), and this seems to be a repetitive feature for the igneous basic and alkaline rocks from an extensive region.

CONCLUSIONS The different gabbroic rocks from Amparo, Jacutinga and Itaoca revealed significant petrologic similarity. The 
mineralogy and textures are basically the same in the three intrusions. Microprobe analysis and geothermometric measurements confirmed similar physical-chemical crystallization conditions for the corona formation with temperatures around $800 / 900^{\circ} \mathrm{C}$. These high temperatures are close to those calculated for the intramagmatic formation of opx-cpx pairs $\left(800 / 940^{\circ} \mathrm{C}\right)$. The absence of consistent regional deformation and the lack of metamorphic paragenesis are compatible with the calculated temperatures. P-T conditions are compatible with the intrusion of the gabbros into the middle / lower

Table 5- Sr isotopic analyses of Jacutinga and Itaoca rocks

\begin{tabular}{|l|c|c|c|c|}
\hline & J470 & J471 & J472 & J475 \\
\hline${ }^{87} \mathrm{Sr} /{ }^{86} \mathrm{Sr}$ & 0.70832 & 070892 & 0.70831 & 0.70757 \\
error & 0.000012 & 0.000012 & 0.000039 & 0.000014 \\
\hline & Ita25 & Ita31 & Ita34 & Ita95 \\
\hline${ }^{87} \mathrm{Sr} /{ }^{86} \mathrm{Sr}$ & 0.70623 & 0.70621 & 0.705394 & 0.705655 \\
error & 0.000017 & 0.000017 & 0.000011 & 0.000012 \\
\hline
\end{tabular}

crust, favoring the development of the sub-solidus reaction. The data is consistent with a slow cooling environment at a late magmatic stage.

Geochemical data show abnormal incompatible elements enrichment. Major, minor and trace element geochemistry and $\mathrm{Sr}$ isotopic data, confirmed the enrichment process. The origin of such enrichment can be attributed to direct or indirect crustal contamination during the orogenic evolution. Nevertheless, in comparison to the values found in the basic rocks, the country rocks have equal to lower contents of Sr and LREE (Ludka et al. 1998). The mantle enrichment through crustal contribution generally raises $\mathrm{Ba}, \mathrm{Rb}, \mathrm{K}, \mathrm{Sr}$ and LREE but not selectively $\mathrm{Ba}, \mathrm{Sr}$ and LREE. The observed enrichment level in the tholeiites could point towards a large-scale crustal contamination. On the other hand, low $\mathrm{SiO}_{2}, \mathrm{Rb}$ and $\mathrm{K}$ contents suggest that crustal contribution was limited. High $\mathrm{Sr}, \mathrm{Ba}$ and LREE-contents together with lower Rb and K contents, as shown by Pearce (1983), are not currently accepted crustal contamination markers. This particular geochemical signature is a repetitive characteristic, observed in several igneous-derived rocks from this region (Ludka et al. 1998). In the paleoproterozoic orthogranulites from the Rio Preto (MG)-Vassouras (RJ) region, the common LILE depletion, typical for granulitic terranes is absent (Heilbron et al. 1997). This selective Rb removal observed in some granulite samples is once more similar to the low $\mathrm{Rb}$ contents found in the younger gabbros from Amparo, Jacutinga and Itaoca, from this work.

A further discussion point is the interpretation of the high $\mathrm{Sr}$ initial ratios, which is also considered by many authors as a strong sign of crustal contribution. The repetitions of this result $(0.705-0.708)$, independent of igneous rock types (from tholeiitic to alkalic) and geological ages (from the Neoproterozoic to the present) are inconsistent with restricted crustal assimilation. Similar results for all intrusions may be rather a result of a mantle Dupal-type anomaly of the Southern Hemisphere (Hart, 1984). The two enriched mantle types end-members of Zindler and Hart (1986), EM1, with higher Ba and lower Sr initial ratio (lower than 0.706), and EM2, with higher isotopic initial ratio but lower Ba are frequently found all over the Southern hemisphere. The results of this study show mixed signatures between the two enriched mantle types. Further $\mathrm{Sm} / \mathrm{Nd}$ and $\mathrm{Pb}$ isotopic analysis are needed to corroborate this correlation. A review of larger data sets from the literature will improve our knowledge of the phenomenon and may confirm the estimated long lasting mantelic geochemical anomaly.

The observed $\mathrm{Ba}, \mathrm{Sr}$ and LREE enrichments and the anomalous isotopic ratios are interpreted in this work as an anomalous underlying mantle and not just an exclusive product of crustal contamination due to the Neoproterozoic subduction event.

Acknowledgements To Bernd Lammerer, Frank Söllner and Klaus Weber Diefenbach for their support with XRF, REE, microprobe and $\mathrm{Sr}$ isotopic analyses during the stay of Isabel Ludka at the IAAG/ LMU with financial support of DAAD/CAPES. CNPq sponsors Cristina Wiedemann-Leonardos and FAPERJ sponsors Isabel Ludka. Field and laboratory work at the UFRJ was financed by CNPq, PADCT and FINEP. To Othon Leonardos and two anonymous referees of RBG for improving this manuscript.

\section{References}

Andersen D.J.1992. QUILF: A PASCAL program to assess equilibria among Fe-Mg-Ti Oxides, Pyroxenes, Olivine and Quartz. Stony Brook Mineral Physics Institute Publication

Braun O. P. G. \& Cavalcante J.C.1980. Geologia das Folhas Cantagalo, Quarteis e Cordeiro - Projeto Carta Geológica do Estado do Rio de Janeiro - DRM/UFRJ- Relatório fi- Proje

Bellieni G., Comin-Ciaromonti P., Marques L.S., Melfi A.J.1984. High and low TiO flood basalts from the Paraná -plateau (Brazil):Petrology and geochemical aspects bearing basalts from the Paraná -plateau (Brazil):Petrology and geochemical aspects bearing
of their mantle origin. N. Jahrb. f. der Mineral., Abhandlungen, 150:273-306

Cox K.G., Bell J.D., Pankhurst R. J.1979. The Interpretation of igneous rocks-George Allen \& Unwin, London, 450p.

Cordani U.G., Civetta L., Mantovani M.S.M., Petrini R., Kawashita K., Hawkesworth C.J. Taylor P., Longinelli A., Cavazzini G., Piccirillo E.M.1988. Isotope geochemistry of flood volcanics from the Paraná basin (Brazil) In:Piccirilo E.M. \& Melfi A.J. (Eds.) The Mesozoic flood volcanism of the Paraná basin:petrogenetic and geophysical aspects.IAG-USP Press, p. 157-178

Dam B.P. 1995. Geodinamics in the Bamble area during Gothian- and Sveconorwegian times - a comparative petrological study of two gabros- $\mathrm{PhD}$ Thesis, University of Utrecht. $114 \mathrm{pp}$

Fontes C.A., Netto C., Costa M.R.A., Baltasar O.F., Silva S.L. da 1981. Projeto Mimoso do Sul. Rel. int. CPRM/DNPM, 248pp., Belo Horizonte.

Hart S.R.1984. A large-scale isotope anomaly in the southern hemisphere mantle. Nature, 309:753-757

Heilbron M., Machado R., Figueiredo M. H. 1997. Lithogeochemistry of paleoproterozoic orthogranulites from the Rio Preto (MG)- Vassouras (RJ) region, central Ribeira Belt, orthogranulites from the Rio Preto (MG)- Vassouras (RJ)

Irvine T.N. \& Baragar W. R. 1971. A guide to the chemical classification of the common volcanic rocks. Can. J. Earth Sci., 8:523-548.

Ladwig L. 1988. Die Gabbro-intrusionen und ihre Rahmengesteine in der umgebung von Itaoca, südliches Espírito Santo, Brasilien, sowie petrographische und geochemische Bearbaitung der basischen Intrusiva. Unpublished Diplomarbeit, LMU, Munich, $176 \mathrm{pp}$.

Le Maitre R.W. (ed.) 1989. A classification of igneous rocks and a glossary of terms. Blackwell, Oxford. 193 pp.

Ludka I.P. 1991. Geologia, petrologia e geoquímica do complexo intrusivo Jacutinga-Torre, Mimoso do Sul, ES. Tese de mestrado, IGEO/UFRJ. 256p.

Ludka I. P., Wiedemann C.M., Töpfner C. 1998. On the origin of incompatible element enrichment in the Venda Nova pluton, Espírito Santo, Brazil- Journal of South America Earth Sciences, 11:473-486.

Middlemost E.A.K. 1975. The basalt clan. Earth Sci. Rev., 11:337-364

Middlemost E.A.K. 1985. Magmas and magmatic rocks. Longman Group limited, Essex.
Offman R. 1990. Geologische, petrographische und geochemische charakterisierung des Intrusivkomplexes von Iconha im südlichen Espírito Santo, Brasilien sowie petrogenetische interpretation. Unpublished $\mathrm{PhD}$ thesis, LMU, Munich. $268 \mathrm{p}$.

Pearce J.A. 1975. Basalt geochemistry used to investigate past tectonic enviroments on Cyprus. Tectonophysics, 25:41-67.
Pearce J.A. 1983. Role of the sub-continental lithosphere in magma genesis at active continental margins. In: C.J. Hawkesworth \& M.J. Norry (eds.), Continental basalts and mantle xenolits. Shiva, Nantwich., p. 230-249

Söllner F., Lammerer B., Weber-Diefenbach K. 1991. Die Krustenentwicklung in der Küstenregion nördlich von Rio de Janeiro/Brasilien.München Geologische Hefte, 4, 100 p.

Sun S.S \& McDonough W.F. 1989. Chemical and isotopic systematics of oceanic basalts: implications for mantle composition and processes. In: Magmatism in the ocean basins. Geological Society, Special publication, 42:313-345

Vieira V.S., Raposo F.O., Delgado I.M. 1993. A granitogênese brasiliana na evolução do Cinturão Móvel Costeiro em áreas do Espírito Santo e Minas Gerais. In: Workshop Mag. Gran. e Miner. Assoc. Res. Exp. e roteiro de excurção. Publ. Esp. da Acad. Bras. Cienc: 83-86.

Wells P.R.A. 1977. Pyroxene thermometry in simple and complex systems. Contrib. Mineral. Petrol., 62:129-139.

Wiedemann C.M. \& Lammerer B. 1983. Evidências do caráter ígneo estratiforme do Complexo Jacutinga- Torre, Mimoso do Sul, ES. In: Anais da Acad. Bras. Ciências, 55:326

Wiedemann C.M. \& Ludka I.P. 1984. Contribuição à geologia e petrografia do complexo Jacutinga-Torre, Mimoso do Sul, ES. In: Congr. Brasil.. Geol. 33. Anais... Rio de Janeiro, SBG: 6:2723-2737

Wiedemann C.M., Bayer P. Horn H., Lammerer B., Ludka I.P., Schmidt-Thomé R. Wever_Diefenbach K. 1986a. Maciços intrusivos do sul do Espírito Santo e seu Wever_Diefenbach K. 1986a. Maciços intrusivo

Wiedemann C.M., Weber-Diefenbach K., Ludka I.P. 1986b. Introduçäo 'a Geoquímica de elementos maiores, menores e traços do Complexo Jacutinga-Torre, Mimoso do Sul, E.S. In: Congr. Brasil. Geol., 34, Goiânia, Anais..., 6:2877-2890

Wiedemann C.M., Mendes J.C., Ludka I.P. 1995. Contamination of mantle magmas by crustal contributions - evidence from the Brasiliano mobile belt in the states of Rio de Janeiro and Espírito Santo, Brazil. Anais Academia Bras. Ciencias, 67:279-292.

Winchester J.A. \& Floyd P.A. 1976. Chemical magma type discrimination; application to altered and metamorphosed basic igneous rocks Earth Planet. Sci. Lett., 28:459-469.

Winchester J.A. \& Floyd P.A. 1977. Geochemical discrimination of different magma series and their differentiation products using immobile elements. Chemical Geology, 20:325-343

Wood B.J. \& Banno S. 1973. Garnet-Orthopyroxene and Orthopyroxene-Clinopyroxene Relationships in Simple and Complex Systems. Contrib. Mineral. Petrol., 42:109124.

Zindler A. \& Hart S.R. 1986. Chemical geodynamics. Ann. Rev. Earth and Planet. Sci. Letters, 14:493-571 